\title{
Recruiting and Retaining Teachers in the UK: An Analysis of Graduate Occupation Choice from the 1960s to the 1990s
}

\author{
Arnaud Chevalier* Peter Dolton** and Steven McIntosh*
}

November 2001

\begin{abstract}
This paper examines the market for teachers in the UK from 1960 to the mid 1990s using graduate cohort data from 5 separate cohorts. The use of this data allows us to simulate the effect of possible teacher pay rises over time. We find that relative wages in teaching compared to alternative professions have a significant impact on the likelihood of graduates choosing to teach, although the impact depends upon the market situation at the time. The wage effect on the supply of teachers is strongest at times of low relative teachers' wages, or following a period of decline in those wages. It is also strongest for those individuals who have more recently graduated.
\end{abstract}

* Centre for Economic Performance, London School of Economics

** University of Newcastle-upon Tyne, Institute of Education, University of London and CEP, LSE 


\section{Introduction}

A matter of continuing concern for public policy in the UK is a shortage of schoolteachers in general, and in certain subjects and geographical areas in particular. The Department for Education and Skills' own figures suggest a shortfall in the supply of teachers of some 34,000 , divided approximately equally between primary and secondary teachers ${ }^{1}$. Particular subjects, such as maths and the sciences, and particular areas, such as London and the SouthEast, have suffered severe shortages of teachers in recent years.

In the Zabalza et al (1979) model of the labour market, the demand for teachers is formulated in terms of the number of children of school age, and the government's own desired pupilteacher ratio. Clearly, if the government was willing to accept higher class sizes then it could cut the demand for teachers immediately by increasing its desired pupil-teacher ratio. In the current political climate, with numerous pressures on the government to cut class sizes and improve key stage examination performance, this option is unlikely to be adopted. The other factor determining the level of demand for teachers, the number of children who require teaching, is outside government control. It would therefore appear that the most feasible route for reducing the excess demand for teachers is via an increase in their supply. It is thus upon the supply of teachers that this paper focuses.

The supply of teachers can be regarded as all those currently in teaching, plus those currently not teaching, but who are qualified to teach, and would consider teaching if the conditions were right. The supply issues at stake are therefore ones of recruitment and retention, as well as inducing the return of individuals who have left the profession. There are many factors that are likely to influence the supply of teachers, such as the relative earnings on offer in teaching and other careers, other labour market opportunities, and varying relative nonpecuniary conditions of work. To a certain extent, some of these factors can be controlled by the government, for example, the earnings that teachers receive, and so public policy can have an influence on supply. The aim of this article is to evaluate some of the factors that influence the supply decisions of teachers, so that policy initiatives to increase the supply can

\footnotetext{
${ }^{1}$ The details of this calculation are contained in Appendix A and the whole post-war position relating to supply and demand for teachers is summarised in Figure A1.
} 
be formulated. We do this using a series of data sets that provide information on five cohorts of individuals, who graduated from higher education in 1960, 1970, 1980, 1985, and 1990. The use of such data allows us to consider both characteristics of individuals that vary across any cross-sectional group of respondents, and factors that are common to all individuals in a particular cohort, but which have varied over time, such as the state of the graduate labour market.

Much of the analysis that follows focuses on the earnings that individuals can earn as teachers, relative to what they could earn in alternative occupations, as one of the key determinants of the decision to become a teacher. It is likely that non-pecuniary factors such as workload, job stress, physical surroundings and related factors also play an important role in the decision to enter teaching. Indeed, anecdotal evidence would suggest that such conditions are adversely perceived by current and potential teachers, which can have a real effect on reducing the supply of labour to teaching. Unfortunately, our data sets do not contain measures of such working conditions, and so our focus is on more quantifiable determinants such as levels of remuneration ${ }^{2}$.

To aid the interpretation of the empirical results that follow, some documentation of teachers' earnings would be useful. Figure 1 shows how the average real earnings (in 2001 pounds) of female secondary school teachers ${ }^{3}$ aged under 25 and between 35-39 have changed over time $^{4}$. The graph shows a slow upward trend with an age differential that has remained roughly constant over time.

\footnotetext{
${ }^{2}$ In a related paper (Chevalier et al (2001), we do consider reported satisfaction with a number of aspects of working life, using data from the 1985 and 1990 Graduate Cohort Data Sets used below. The results suggest that teachers are less satisfied than other graduates concerning key aspects of their jobs, such as pay and hours worked.

${ }^{3}$ The average earnings of male teachers follow a similar pattern.

${ }^{4}$ The vertical lines show the points in time at which our five cohorts are observed. Cohort 1 are 1960 graduates observed in 1966, cohort 2 are 1970 graduates observed in 1977, cohort 3 are 1980 graduates observed in 1986, cohorts 4 and 5 are respectively 1985 and 1990 graduates observed in 1996.
} 


\section{Figure 1: Female Secondary Teachers' Real Wages (2001 £) by Age Group}

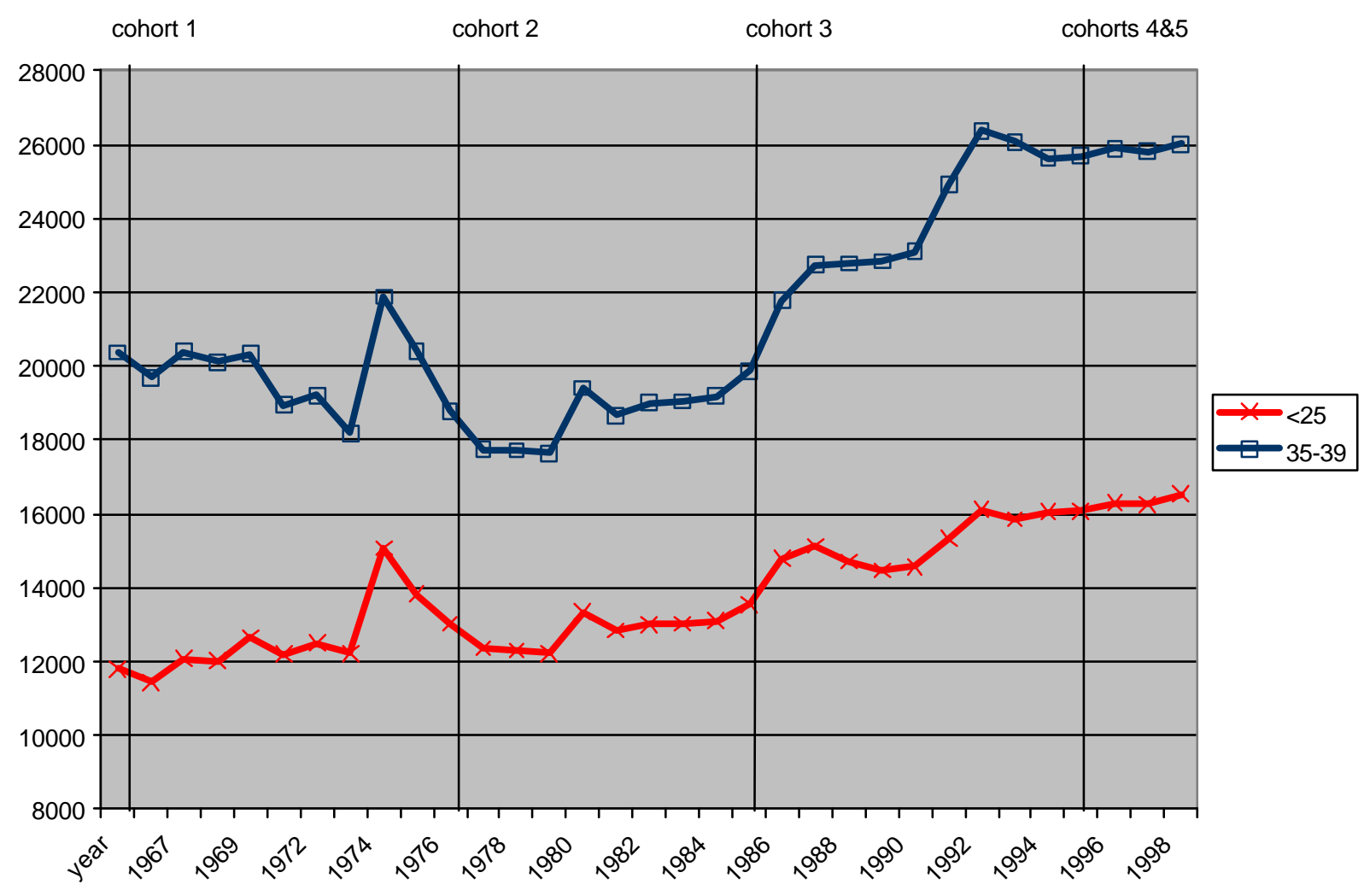

Of prime importance, however, is teachers' pay relative to other graduate occupations, since we wish to consider how graduates make choices between becoming a teacher and taking up another occupation. Figure 2 graphs the relative earnings of teachers compared to average non-manual earnings and national average earnings ${ }^{5}$. The highest relative wages were paid to teachers in the mid-1960s, followed by a considerable deterioration in the period up to 1973. There followed a series of dramatic adjustments after the Houghton Report (1974) and the Clegg Commission (1980) recommended that teachers' pay had been allowed to decline too far. More recently, the 1990s have seen a continuous decline in the relative wage of teachers, although of less dramatic extent than the decline of the late 1960s and early 1970s.

\footnotetext{
${ }^{5}$ Data on earnings are available from two sources, the October survey of earnings and, since 1968, the New Earnings Survey (NES). With respect to average earnings of all employees, the two surveys give similar estimates over the period that they are both in existence, and so the reported average earnings is a simple average of the two estimates. For specifically non-manual earnings, the DfES's Labour Market Trends (formerly the Employment Gazette) reports an index based upon the October Survey until 1970, and from then onwards, the NES. However, the resulting estimate is considerably above the estimate of non-manual earnings supplied by the NES, and so in Figure 3, we only display teachers' earnings relative to the non-manual average from 1968 onwards using the NES. We estimate the position relative to non-manual earnings for 1966 (to gauge the situation for our first cohort), by adding the average difference between the October Survey and NES
} 
Such fluctuations in the relative level of pay for teachers will be important for the interpretation of the empirical results that follow.

Figure 1: Female Secondary Teachers' Real Wages (2001 $£)$ by Age Group

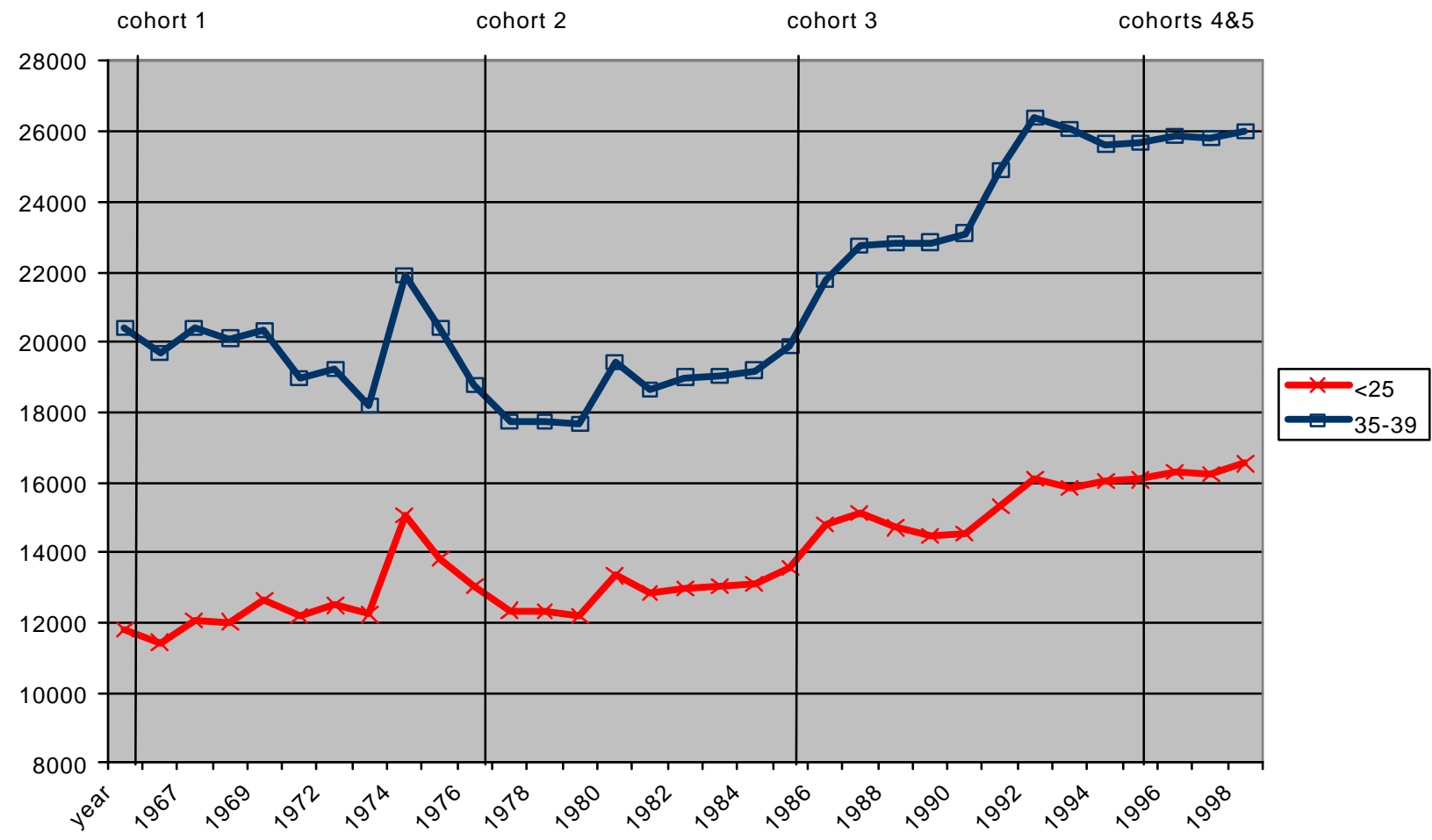

The following section outlines a simple model of the labour market for teachers, illustrating how a situation of excess demand (or insufficient supply) can arise. The paper then goes on to describe some of the factors that have been found in the literature to affect the labour supply of teachers. We then describe the graduate cohort data sets that we use, and outline our methodology for analysing the supply decisions of teachers. The results of the statistical analysis for all the data are presented in section 6 . The analysis is then repeated for each cohort separately in the following section and these results are used to address policy questions, such as the effect of a $10 \%$ relative pay rise for teachers. A final section concludes. 


\section{The Labour Market for Teachers}

Following Zabalza et al (1979), the labour market for teachers can be thought of within a traditional supply and demand framework, with the additional complication that the government is virtually the sole hirer of labour, the private sector in the UK accounting for no more than $5-7 \%$ of all teachers hired.

Demand for teachers is determined by the number of children in the country of school age, and the government's desired pupil-teacher ratio. For a given such ratio, the demand for teachers is therefore a constant, denoted by $Q^{*}$ in Figure A2. Under the reasonable assumption that the supply of teachers is a positive function of average teacher earnings, an upward-sloping labour supply schedule can be drawn as S. In a perfectly competitive market, a wage of $\mathrm{W}^{\mathrm{a}^{*}}$ would therefore clear this labour market. However, the teachers' labour market is of course not competitive, and the government, in its role as (almost) exclusive purchaser of teaching labour, has other considerations, prime amongst which is the level of expenditure on teachers' salaries in total. For a given level of such expenditure, an inverse relationship can be plotted between teachers' earnings and the number of teachers hired, labelled $\mathrm{E}_{1}$ in Figure $\mathrm{A} 2$; if the government wants to raise the salaries of teachers, it can afford to hire fewer of them, given a fixed budget. The number of teachers hired is therefore $\mathrm{Q}_{\mathrm{g}}$ at average earnings of $\mathrm{W}_{\mathrm{g}}^{\mathrm{a}}$, and the excess demand for teachers is $\mathrm{Q}^{*}-\mathrm{Q}_{\mathrm{g}}$. This can only be eradicated by a relaxing of the budget constraint leading to higher earnings, or other factors changing to make teaching more attractive, so that more potential teachers supply their labour at any given wage. This paper examines the supply responses to changes in wages, and other factors.

Of course, the above analysis is simplistic in that it treats all teachers as being the same. In reality, there may be teacher shortages in particular regions or in particular subjects, with an over-supply elsewhere. In addition, the real market position is very different for primary and secondary school teachers. We can amend Figure A2 to allow for such possibilities by creating a simple distinction of different kinds of teachers. A simple analysis would suggest that the possibility of differential wages by subject, in different regions or between primary and secondary sectors could be adopted to solve the problems of short supply in particular areas. Whether this solution is actually viable, given the demands of teachers' unions and the political process in general, is another question. In the empirical analysis that follows, we 
allow for the possibility that supply responses differ by subject of study amongst potential teachers. First though, we review some of the evidence that has been collated on the supply decisions of teachers.

\section{The Literature on the Supply of Teachers}

A large literature exists on the factors affecting the supply decisions of teachers, most of it originating in the US. This literature can be divided into studies that examine the influences on the decision to enter teaching, and the influences on the decision to exit from teaching. A few studies also consider quality aspects of teachers.

Considering first the entry decision, British work on this topic is limited. Dolton (1990) uses data from the 1980 Graduate Cohort, which follows a sample of graduates for up to seven years after they have graduated. In this, and most other work in this area, wages are shown to be an important factor in the decision to become a teacher. Specifically, relative starting wages in teaching (compared to estimated potential earnings elsewhere) are positively related to the probability of becoming a teacher. In addition, individuals are more likely to become teachers the greater is the growth over time in teachers' earnings, and the lower is the growth in earnings of non-teachers.

A much earlier study, based only on time series data at the aggregate level in the UK for the years 1963-1971 by Zabalza et al (1979), estimates the elasticity of the supply of labour into teaching, with respect to relative teacher earnings. The estimated elasticities range from 2.43.9 for men, and from 0.3-1.8 for women, depending on the definition of alternative wages used. When teaching wages are split into starting wages and wage growth, the authors find that the effect of the relative level of starting wages in teaching is similar for both sexes, while the effect of teacher wage growth over time is much greater for men. This suggests that the wage effects are greater for men primarily because of their consideration of career prospects.

There are a similarly small number of US studies to have considered the entry decision into the teaching profession. An example is Manski (1987), who uses data from the National Longitudinal Survey of the High School Class of 1972. The results of his probit equation on occupational choice (teacher/non-teacher) suggest a $10 \%$ increase in weekly teaching 
earnings will raise the supply of teachers from $19 \%$ to $24 \%$ of the graduate cohort. Manski also considers the quality aspect, and calculates that a $10 \%$ increase in weekly teaching earnings, coupled with a minimum requirement for entrance to the profession of an 800 SAT score, would maintain the supply of teachers at $19 \%$ of the cohort, while raising the average academic ability amongst that group to the national average for college graduates.

There are more studies examining the decision to continue in or exit from teaching. Most of the British work in this area has been undertaken using information on various cohorts of university graduates, for example Dolton (1990), Dolton and van der Klaauw (1995a, 1995b, 1999) and Dolton and Mavromaras (1994). With the exception of the last of these studies, all use data from the 1980 Graduate Cohort. The Dolton (1990) study estimates a probit equation on whether an individual is in a teaching job seven years after graduating (conditional on choosing a teaching job as the first job upon graduation). The results suggest that the factors affecting the decision to continue teaching are very similar to those that affect the decision to become a teacher in the first place. The three papers by Dolton and van der Klaauw all adopt a hazard approach to model the length of time spent in the first job after graduation amongst teachers. The results show that the elasticity of leaving a teaching job with respect to relative wages is about -1.5 , suggesting a large reduction in quit behaviour amongst teachers, following a rise in earnings. The importance of the outside labour market and alternative opportunities is also clearly demonstrated by the significance of other variables in the estimated equation. In particular, teachers are more likely to leave their jobs, if their local unemployment rate is low, if they have a professional qualification and if they hold a non-education first degree. When Dolton and van der Klaauw (1995b, 1999) extend earlier (1995a) work by adopting a 'competing risks' approach to their hazard rate, allowing the explanatory variables to have a differential impact on the likelihood of leaving for nonteaching work, and the likelihood of leaving the labour force altogether, they find that a higher teaching wage reduces the probability of teachers leaving the labour force altogether, while a higher predicted wage in the non-teaching sector is related to an increased likelihood of moving into a non-teaching job.

The final paper to use the UK graduate cohort data sets is that of Dolton and Mavromaras (1994), which, using data from both the 1970 and the 1980 cohorts, is the only one to provide, as we do here, comparisons over time. The authors decompose the cause of the fall in the likelihood of becoming a teacher between these two dates into changes in the 
characteristics of the individuals themselves, and changes in the characteristics of the job market that they face. The results reveal that the fall is due almost entirely to deteriorating market conditions for teachers.

As with the entry into teaching decision, Zabalza et al (1979) also undertake a time series analysis of the exit decision, considering the years 1963-1972. As with the Dolton and Mavromaras (1994) study above, they find that males are much more likely to be influenced by wages than females, the elasticity of the trained graduate separation rate with respect to relative wages being -2.4 to -3.0 for men, and -0.6 to -0.7 for women. Unlike their analysis of the entry decision, Zabalza et al find that this gender differential in wage effects exists for both starting wages and the growth in wages.

Turning to the US literature on the continuation or exit decision, the evidence closest in spirit to the UK studies using the graduate cohort data sets is provided in two papers by Stinebrickner (1998, 2001), using data from the National Longitudinal Study of the High School Class of 1972. As was found with the UK studies, Stinebrickner (1998) suggests that teachers are more likely to stay in their job, the higher are the wages that they receive. Stinebrickner (2001) simulates the effects of changing teacher wages. Two policies are considered, the first being a $25 \%$ pay increase for all teachers, and the second being a $25 \%$ pay increase on average, the actual amount depending linearly on teachers' SAT scores. The results of the simulation show that the proportion of the eleven years under consideration that the initial teachers spend in teaching, rises from 0.48 to 0.72 under both of these policies, with wage increases being particularly likely to reduce the amount of time spent in nonteaching employment, rather time spent out of the labour force altogether. The second policy, whereby wages are increased in proportion with teacher quality, leads to a change in the mix of teachers towards a greater proportion of those of high quality. A limited number of other papers have also considered this quality aspect. For example, Ballou and Podgursky (1995) suggest that wage rises must be implemented together with an attempt to target those of higher ability, or, more cost effectively, making the pay rise conditional on having a certain minimum SAT score, if quality is to increase. In a similar vein, Hanushek et al (1999), using data for the years 1993-1996 from the UTD Texas Schools Project database, show that a $10 \%$ increase in starting wages is associated with a $2 \%$ fall in the probability of leaving for probationary teachers, and a $1 \%$ fall for those with 3-5 years of experience. The 
same wage increase is also associated with higher maths and reading achievement amongst pupils of 0.17 and 0.11 standard deviations respectively.

Finally, summarising the remaining US papers to have studied the exit decisions of teachers, many have used state level data on all teachers registered within particular states, including Brewer (1996,) Rees (1991), Mont and Rees (1996) (all studying New York), Murnane and Olsen (1989) (Michigan), Murnane and Olsen (1990) (North Carolina), Theobald (1990), and Theobald and Gritz (1996) (both Washington). All agree that the salary paid to teachers is negatively related to their propensity to leave, or positively related to the duration spent in first teaching jobs. Where studies allow for gender differences, a common finding is that these wage effects are larger for men than for women. In addition, the results generally show that teachers with higher level qualifications, or who live in areas with higher average nonteaching wages, and more likely to leave their teaching jobs.

\section{Data}

We turn now to our own analysis of the decisions to enter and continue teaching. The data used in this analysis come from five cross-sections of UK university graduates covering the period 1960 to 1996. Each cohort was surveyed approximately six years after graduation apart from the 1985 cohort, for whom eleven years passed between graduation and the date of survey.

The 1960, 1970 and 1980 cohorts have been used extensively. These surveys are nationally representative of the graduate population sampled from all universities. The 1985 and 1990 cohorts are also representative, but are based on a different design. Individuals were contacted through their institution of origin, and a representative selection of institutions was used to conduct these surveys. Comparisons across surveys are also complicated by the modifications to the Higher Education sector in the UK. From the mid-sixties until the early nineties, two types of Higher Education institutions co-existed: universities and polytechnics, the latter providing a more vocational education. This distinction was abolished in 1992. Concomitant to this institutional change, the proportion of a cohort attending Higher Education has also increased drastically over the period, from about $6 \%$ in the 1960 s to around $30 \%$ in 1995. 
The surveys provide data on a range of variables that are likely to influence the decision whether to teach or not. Key amongst these is the wages received in different occupations. A measure of relative earnings in teaching is derived, as explained in the following methodology section. We also control for the local labour market by including a dummy variable for whether the individual lives in London or the South-East or not, because of the vastly different labour market in that area, as well as the perception of poor working conditions in London's schools. Qualifications may also have an impact on the teaching decision, independently of their effect through the alternative wage that could be earned in the labour market. Thus, we control for A level scores, subject and class of degree, type of institution attended and any higher qualifications obtained. It is expected that those individuals who do not study for an education degree are less likely to go into teaching. Particular subjects, such as engineering and science may be particularly unlikely to lead to a teaching career, because of the availability of other options for holders of such degrees. Similarly, postgraduate and professional qualifications should also open up new possibilities in the labour market, reducing the likelihood of an individual teaching. There is also currently a fear that the most academically able graduates do not choose to become teachers. It was hoped that the data on A level and degree results, and type of institution attended, may have allowed us to explore this possibility. However, the problem with using degree results as a measure of graduate quality is that they may not provide consistent standards through time, since the numbers achieving the best results have increased over the period considered. For example, whereas $28 \%$ of graduates obtained a First Class or Upper Second Class in 1960, this figure had increased to $48 \%$ by 1990 (see Table A1).

The remaining variables included in the analysis control for various demographic factors, which may or may not influence the decision to become a teacher. In particular, we include variables for gender, whether the respondents were mature students, marital status, type of school attended, and the socio-economic background of the individuals' families. Finally, we add dummy variables to indicate the cohort to which each individual belongs, to determine whether there is any trend in the decision to become a teacher, irrespective of the trends in the other variables listed here.

Table A1 provides descriptive statistics for each of these variables, separately by cohort. Differences in the background of the cohorts can be noted. In the earlier cohorts, the majority of the graduates are male, but by 1990 the cohort is split evenly between men and women. 
The proportion of mature students has also increased from $7 \%$ to $16 \%$. Both of these facts could be associated with an increase in the teacher supply as ceteris paribus female and mature graduates are more likely to choose a teaching occupation. Despite the increase in the proportion of a cohort reaching Higher Education, universities are still largely dominated by students from the most favoured backgrounds (as measured by paternal social class and the overrepresentation of those individuals who attended private school). Finally, a higher proportion of recent cohorts have graduated from a (former) polytechnic institution.

Current earnings do not appear to have varied a great deal over time for graduates, which is in contradiction with evidence that returns to higher education have increased over the period (Chevalier and Walker, 2001). This may be partly due to differences in the collection of the data. While the 1960, 1970 and 1980 cohorts reported their earnings, for the last two cohorts earnings were reported as a categorical variable. Also note that the earnings variable used is a real measure of earnings (1970 £'s), deflated by the index of non-manual earnings, which have grown more rapidly than the usual 'all earnings' or retail price index (RPI) deflators.

Finally, since we are interested in the dependent variable of becoming a teacher, then we are interested in the proportion that do so in each cohort. These figures appear in Table A1, revealing that although close to $30 \%$ of the 1960 cohort worked as teachers six years after graduation, this proportion fell to $11-15 \%$ in later cohorts. Of course, this is likely to be in large part due to the rapid increase in the number of graduates, which has far outstripped the growth in the demand for teachers, implying that we should expect a lower proportion of a graduate cohort to enter teaching now compared to earlier times.

\section{Empirical Methodology}

We turn now to the methodology used to estimate our equations, which is similar to that in Dolton (1990), and a full description can be found there. The key equation that we want to estimate is a probit equation for whether graduates are currently in teaching or not, usually six years after graduation. Algebraically, the equation can be represented as:

$T_{t}=\beta_{0}+\beta_{1}\left(\ln W_{t}^{T}-\ln W_{t}^{a}\right)+\beta_{2} T_{1}+\underline{\beta}_{3} \underline{X}+u_{1}$

$\mathrm{T}_{\mathrm{t}}$ is a dummy variable, taking the value of 1 if the individual is a teacher at time $t$, the time of the survey, and 0 otherwise. The key explanatory variable is the relative wage that the 
individual can expect to earn at time $t$, expressed as the difference between the wages that could be earned as a teacher, $\mathrm{W}_{\mathrm{t}}^{\mathrm{T}}$, and the wages that could be earned in an alternative job as a non-teacher, $\mathrm{W}_{\mathrm{t}}^{\mathrm{a}}$. The variable $\mathrm{T}_{1}$ takes the value of 1 if the individual's first job following graduation was as a teacher, and 0 otherwise, and thus controls for possible inertia effects, such that an individual is more likely to be a teacher now if they originally chose to be a teacher. Finally, the $\mathrm{X}$ vector includes all of the other variables discussed above.

The variable indicating those who chose to teach in their first job is clearly endogenous, and hence a reduced form probit equation for choice of first job is estimated, and the predicted values used in the estimation of the structural equation given above. Likewise, to obtain the wage variables, we estimate two wage equations, one for all current teachers and one for all non-teachers in the sample, and take the predicted values of these as the wages that individuals could earn at time $t$ in the teaching and non-teaching state. Of course, we only observe teachers' wages for those who chose to be teachers, and we only observe nonteachers' wages for those who chose not to teach. It is thus necessary to allow for this selectivity. We therefore estimate a reduced form version of equation 1, omitting the wage and first job choice variables, and then place the inverse Mills ratio from this equation into the estimated wage equations:

$$
\begin{aligned}
& \ln W_{t}^{T}=\delta_{0}^{T}+\underline{\delta}_{1}^{T} \underline{X^{\prime}}+\sigma^{T} \rho^{T} \lambda+u_{2} \\
& \ln W_{t}^{a}=\delta_{0}^{a}+\delta_{1}^{a} \underline{X^{\prime}}+\sigma^{a} \rho^{a} \lambda+u_{2}
\end{aligned}
$$

where $\ddot{e}$ is the inverse Mills ratio, and $\underline{X}^{\prime}$ is a subset of the vector of variables in the occupation choice equation. In particular, the marital status, type of school and socioeconomic background variables are omitted from the wage equations, in order to provide the identifying restrictions for the selection equation. The choice of these instruments is determined principally by the available variables in the graduate cohort datasets, and it should be acknowledged that they are far from perfect. Nevertheless, the results in the next section show these variables to have a significant effect upon occupational choice, while there is no theoretical reason for including them in the wage equations. Finally, $\underline{X}^{\prime}$ also includes some variables not in the occupation equations, but which are frequently found in wage equations, namely work experience and its square, and part-time status. Since the wage differential variable, as well as the probability of teaching in the first job, is an estimated variable, standard errors calculated in the usual way would be biased. We therefore bootstrap the estimates (500 times), in order to get unbiased standard errors. 


\section{The Factors Affecting the Decision to Work as a Teacher}

This section describes the results of the empirical analysis described above. The first stage is to estimate the reduced form equation for the occupation choice (teaching or non-teaching) in the first job. The results are contained in Table A2. The table displays both the estimated coefficients in the probit equation, and the marginal effects. However, since the determinants of the first job choice are similar to those of the current job choice, to be discussed below, the first job choice coefficients will not be discussed here.

Table A3 contains the results for the wage equations. In column 2 the results of the selection equation on choice of current job are displayed. The inverse Mills ratio from this equation is then included in the wage equations for teachers and non-teachers, in columns 3 and 4 respectively (denoted 'lambda'). The significance of the coefficient on this variable in both wage equations reveals the importance of allowing for selectivity into the teacher or nonteacher states. The remaining coefficients in the wage equations are as we would expect, and display the same sign, even if they do differ in magnitude, for both teachers and non-teachers. Thus we observe higher wages for males, those with a better class of degree and higher A level scores, those with postgraduate and professional qualifications, those who live in London or the South-East, those with more work experience and those who work full-time. The degree subject coefficients do vary by occupation, with the results suggesting, somewhat surprisingly, that all subjects attract a significantly positive wage differential with respect to the omitted category of education degrees in teaching jobs, while in non-teaching jobs, there are fewer statistically significant differences, with only those holding a language or arts degree earning less than those with an education degree.

Our main results relate to the choice of current occupation, as displayed in Table A4. We consider first the wage variable. For each individual, we include the predicted wage differential (the predicted wage in teaching minus the predicted wage in non-teaching) as a determinant of occupation choice. The marginal effect in the final column shows that a $10 \%$ rise in teacher earnings, relative to non-teacher graduate earnings, will increase the probability of an individual becoming a teacher by 5.4 percentage points. Given that the teaching probability ranges from approximately 10-15\% (with the exception of the 1960 cohort), this is a very sizeable effect. Increasing wages would clearly be an effective method of persuading more graduates to become, and remain, teachers. 
The subject specialisation variables also reveal some interesting determinants of the decision to teach. As expected, the subject coefficients show that graduates who studied for an education degree are more likely than those of all other subjects to enter teaching. The difference is greatest for engineering graduates, who have pursued a profession-orientated subject themselves that offers good prospects in terms of job opportunities, because of a lack of suitably trained graduates in this field. Outside options are also responsible for the coefficients on the professional qualifications, $\mathrm{PhD}$ and MSc variables, all of which show that individuals with such qualifications are less likely to work as teachers. Presumably, such individuals had other careers in mind when they embarked on such studies, since none are required to enter the teaching the profession. We should not be surprised, therefore, that on the whole they have followed these career paths. In addition, graduates with a first class or upper second class degree are less likely to teach than those with lower degree classes, holding the other factors in the equation constant, which, recall, includes alternative wages. Although the marginal effect is quite small (a 1.6 percentage points lower probability of teaching), this difference is statistically significant. Thus, holding constant the relative wages on offer in teaching and non-teaching occupations, there appears to be some non-pecuniary cost to teaching for those with a good class of degree. Perhaps such graduates believe that their high level skills are better suited to alternative employment. The other variables included in the equation to try to capture quality effects, namely the A level scores of the respondents and whether they attended a university or polytechnic, do not attract statistically significant effects.

Turning to the cohort effects, there is a clearly observable pattern, the coefficients declining monotonically with each successive cohort (with the exception of the 1985 cohort). All cohorts are significantly less likely to teach than the 1960 cohort. Thus, holding all other factors in the equation constant, individuals in each cohort are less likely than those in the cohort before to go into teaching, apart from a small rise in the probability between the 1980 and the 1985 cohorts. Given that the early 1980s saw a very deep recession in the UK, the high levels of unemployment and subsequent lack of alternative employment may have persuaded graduates at this time to look for a job in a relatively recession-free profession such as teaching. The largest change in the probability of teaching seems to have occurred between the 1960 and 1970 cohorts, with a 6.2 percentage point fall in the probability of becoming a teacher, holding other things constant, between these dates. There was also a 4.0 
percentage point fall in this probability between the 1985 and 1990 cohorts. Thus there appears to be an increasing trend away from teaching as a profession, even if other factors had not changed ${ }^{6}$. The fact that relative wages in teaching have, on the whole, fallen over this period, merely re-enforces this trend away from teaching.

The remaining statistically significant effects in Table A4 suggest that men are 4 percentage points less likely to teach than women and that married graduates are 1 percentage point more likely to teach than single graduates. There is some evidence that social class influences the decision to go into teaching, since those individuals who attended a private school for their education, and those who came from a family with a professional head of household, are both less likely to choose teaching than state-educated and none-professional family graduates. The dummy variable indicating graduates who live in London and the South-East attracts a statistically significant coefficient, which reveals that, holding other things constant, individuals in this area are over 6 percentage points less likely to teach than individuals in other areas. This is most probably as a result of the wide range of alternative professional occupations available in London, compared to other areas, although it is also a possibility that working conditions in London's schools are perceived to be worse than in more provincial areas. Finally, the coefficient on the first job variable shows that, unsurprisingly, those individuals who initially chose teaching as a career immediately after graduation are more likely to still be teaching in their current job than those who chose an alternative first job, the difference in the probabilities being over 9 percentage points. This is due to inertia in the teaching profession, as in many other occupations, so that the non-pecuniary benefits or individual characteristic traits that originally attracted graduates to teaching continue to have an effect six years later.

\section{Cohort Effects and Simulations}

In the previous section we reported the combined regression results for all the cohorts of graduates for which data are available. In this section we confirm that these general results

\footnotetext{
${ }^{6}$ An alternative interpretation is that, given the number of graduates has increased much faster than the number of teaching positions since the 1960s, we would naturally expect a fall in the probability of any particular graduate becoming a teacher. Note, however, that the continuing excess demand for teachers does not suggest that graduates are increasingly choosing an occupation other than teaching because of a lack of available teaching positions.
} 
hold for each of the cohorts separately and use the results of the estimations to perform some simulations of possible policy changes.

Looking at Table A5, which relates to the probit estimations for each of the cohorts separately, we see that many of the factors that operate in the aggregate equations are also at work in separate cohorts. A useful way to summarise the influences on the decision to teach, and how these have varied in the different cohorts, is to calculate the probability of becoming a teacher for a person of fixed characteristics, and then to see how this probability has changed over time, and also how it changes as we vary certain characteristics. Thus, we define a base individual (Individual 1) as a man, with an A level score of 10, graduating in an Arts subject at a university with a $2 / 1$ or above and not living in London. The other characteristics of this individual will be held constant across all of our stylised individuals (see the note at the bottom of Figure 3). We then define another 4 individuals, each of whom has one characteristic that is different to individual 1: Individual 2 has lower ability (A-level score $=6$ ) and graduated with a 2/2 or below, Individual 3 graduated from Science, Individual 4 lives in London and Individual 5 is a woman. The predicted probabilities of being a teacher over time for these various individuals are reproduced in Figure $3^{7}$.

For all types, the probability of currently being a teacher has declined through time. For Individual 1 for example, this probability was 43\% in 1966 (cohort 60), but down to 8\% in 1996 (cohort 90). This is an obvious consequence of the smaller proportion of graduates becoming teachers, which is partly because the number of graduates has expanded dramatically over the years. Hence what is of most concern to us in this figure is the difference between our 'stylised individuals' rather than the declining probability over time. Individuals with lower academic results and women are more likely to be teachers than our base individual, while for individuals with a science degree or living in London the probability of being a teacher is lower, although all differences have been reduced over time ${ }^{8}$.

\footnotetext{
${ }^{7}$ For these calculations, we do not want to use the conditional estimated coefficients presented in Table A5, where the probability of teaching is conditioned on the predicted relative wage and the probability of teaching in the first job, since the characteristics considered are likely to effect relative wages and first job choice. Hence, to obtain the full effect of changes in the various characteristics on the probability of teaching, we use the estimated coefficients from an unconditional probit, full details of which are available from the authors.

${ }^{8}$ For the 1990 cohort, the observed characteristics do not appear to explain much of the variation in the probability of teaching, since all the points, with the exception of the one for which gender is varied, are bunched together.
} 
Figure 3: Predicted Probability of Being a Teacher for Different Type of Graduates.

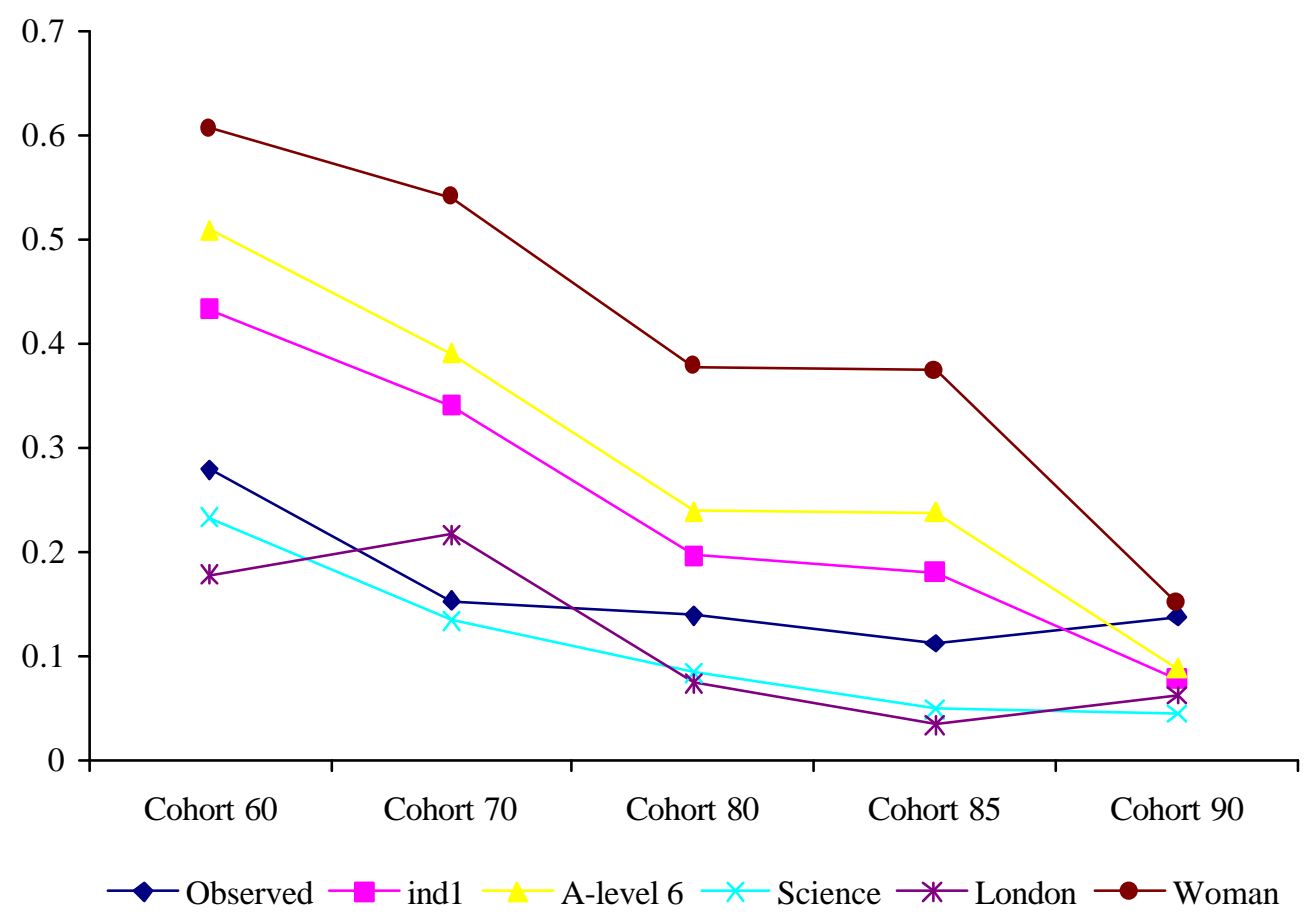

Note: Characteristics held constants for all individuals: University graduate, married, father in interim occupation, no other qualification, state funded school Ind1: Man, Arts graduate, A-level score $=10,2 / 1$ or above, not in London Ind2: Man, Arts graduate, A-level score $=6,2 / 2$ or below, not in London Ind3: Man, Science graduate, A-level score $=10,2 / 1$ or above, not in London Ind4: Man, Arts graduate, A-level score $=10,2 / 1$ or above, live in London Ind5: Woman, Arts graduate, A-level score=10, 2/1 or above, not in London

The remainder of this section will focus on the effect of relative earnings on the decision to teach. We begin by examining the extent to which teacher wages have lagged non-teacher wages over time, using the matching methods pioneered by Rosenbaum and Rubin (1983). In effect, what this method does is to find, for each teacher in our sample, the non-teacher who looks most similar on the basis of observable characteristics, and examine the difference in earnings. We then investigate whether earnings differ by occupation amongst graduates who look the same. Specifically, we estimate a probit equation for the probability of becoming a teacher and use this to predict the 'propensity score' for a graduate to become a teacher. Using different matching methods (nearest neighbour or Kernel methods) gives us the results in Table 1. The table presents the mean current pay differential between teachers and their matched contemporaries. A negative estimate shows the percentage by which teachers earn less than a comparable group of non-teachers. 
Table 1: Matched estimates: Current Pay Differentials between Teachers and similar Non Teachers.

\begin{tabular}{llllll}
\hline & Cohort 60 & Cohort 70 & Cohort 80 & Cohort 85 & Cohort 90 \\
\hline \hline Year Sampled & 1966 & 1977 & 1986 & 1996 & 1996 \\
Years in Teaching & 6 & 7 & 6 & 11 & 6 \\
Relative Wage & 1.41 & 1.21 & 1.15 & 1.22 & 1.22 \\
* One to one match & & & & \\
Bandwidth=0.001 & -0.003 & 0.011 & $-0.085 * *$ & $-0.178^{* *}$ & -0.040 \\
& $(0.003)$ & $(0.028)$ & $(0.029)$ & $(0.079)$ & $(0.047)$ \\
Bandwidth=0.0001 & -0.001 & 0.008 & $-0.115 * *$ & $-0.240 * *$ & -0.026 \\
& $(0.003)$ & $(0.029)$ & $(0.030)$ & $(0.076)$ & $(0.043)$ \\
$*$ Kernel match & & & & & \\
Bandwidth=0.001 & -0.012 & 0.010 & -0.080 & -0.085 & -0.019 \\
Bandwidth=0.0001 & $(0.027)$ & $(0.027)$ & $(0.020)$ & $(0.088)$ & $(0.038)$ \\
Non matched (.001) & $(0.005$ & 0.016 & -0.090 & -0.165 & -0.030 \\
Non matched (.0001) & 35 & $(0.029)$ & $(0.023)$ & $(0.089)$ & $(0.038)$ \\
\hline
\end{tabular}

The results reveal that the teachers most likely to be underpaid relative to observationally equivalent non-teachers are in the 1980 and 1985 cohorts, observed in 1985 and 1996 respectively. The cohort of teachers who began their careers in 1980 are likely to be underpaid relative to comparable non-teachers by $8-12 \%$ in 1986 . This is most likely due to the five years (according to Figure 2) of declining relative wages that they have endured, giving them the lowest relative teacher wages of all of the cohorts. The position for the 1985 cohort is interesting, given that they are observed at the same time (1996) as a later cohort of graduates from 1990. Although the latter group, with only six years experience, are not underpaid compared to similar non-teachers, the teachers in mid-career who have been teaching for 11 years are being underpaid, compared to their matched counterparts, by 9$24 \%$. This comparison thus highlights a further important dimension to the issue of relative pay, that such comparisons are different at different points in the career life cycle.

Given that such there has been such variation in the relative level of teachers' earnings over time, it would be interesting to examine how this variation has affected the numbers entering the profession at each point in time. Many authors researching the teachers' labour market 
have performed simulations using their data to answer questions concerning the potential effect of a pay rise on the supply of teachers. Nearly all of these studies have performed such simulations at a given point in time. By using a series of cohorts we are in the fortunate position of being able to carry out such simulations across time.

Table 2 below performs the simulations. For each cohort, the observed probability is the probability of being a teacher. The predicted probability is calculated for each individual from the probit estimates including the estimated wage differential between teacher and nonteacher status and the probability of being a teacher in the first job. We then increase teachers' relative earnings by $10 \%$, and recalculate this predicted probability of teaching. The change in the probability following this pay rise is shown in the fourth row.

Table 2: Probability of Teaching Before and After a Rise in Teachers' Relative Pay

\begin{tabular}{llllll}
\hline & Cohort 60 & Cohort 70 & Cohort 80 & Cohort 85 & Cohort 90 \\
\hline \hline Observed & 0.279 & 0.153 & 0.139 & 0.112 & 0.138 \\
Predicted & 0.278 & 0.152 & 0.138 & 0.114 & 0.137 \\
\hline Teacher pay +10\% & 0.295 & 0.186 & 0.235 & 0.132 & 0.238 \\
Diff & 0.017 & 0.034 & 0.097 & 0.018 & 0.101 \\
\hline Implied Extra & 378 & 1,717 & 8,420 & 1,827 & 11,360 \\
Teachers & & & & &
\end{tabular}

The figures in the table suggest that, in cohorts 3 and 5, a $10 \%$ rise in teachers' relative earnings would increase the probability of a graduate being in a teaching job six years after graduating by 10 percentage points (that is, in 1996 for example, 24\% of the cohort are predicted to be teaching if the pay rise is implemented, compared to $14 \%$ of the cohort teaching if it is not, which is equivalent to more than a $70 \%$ increase in the actual number of teachers from this cohort of graduates). In the other years the effects of such a pay rise are much smaller. Our suggestion is that these findings are consistent with the national underlying trend in relative teacher wages. The reason for the large potential effect in 1986 is that the relative wage of teachers was at an historically low value of 1.15 against average earnings. Our suggestion for the 1996 effect is that it is less to do with a low relative wage (1.22 against average earnings) but more to do with five uninterrupted years of declining relative wages. In this context teachers were leaving the profession in large numbers and a

\footnotetext{
${ }^{9}$ The implied number of extra teachers is calculated using the number of graduates leaving university (and polytechnics) in $1960,1970,1980,1985,1990$, which are 22,223, 50,494, 86,800, 101,515, and 112,475 respectively.
} 
large pay rise would have had a more marked effect. Note, however, that the 1996 effect is much smaller for the 1985 cohort than for the 1990 cohort. This is perhaps surprising, particularly as Table 1 revealed that the earnings of the 1985 cohort lag those of their nonteaching counterparts by the greatest amount of all the cohorts. If we are arguing that wage increases have the largest effect on the decisions to teach when teachers' relative earnings are low, why then do we not observe a large effect of earnings on the decisions of the 1985 cohort to teach? We can hypothesise that this is due to the amount of time spent in the labour market at the point of observation by the 1985 cohort, eleven years as opposed to six/seven years for all other cohorts, resulting in the graduates of this cohort differing in some unobservable ways from the graduates of the other cohorts. For example, it may be that those individuals who are still teaching in 1996 eleven years after graduating, at a time when teachers' relative earnings have declined for a number of consecutive years and at a point in their careers at which teachers' earnings are falling further behind those of other graduates with similar job tenure, are those individuals who have a particular desire to teach, or are particularly suited to teaching and have poor outside options. Varying wages may have little impact on the decisions to enter, remain or quit teaching amongst such individuals. Thus we can argue that the effect of a wage increase will be most pronounced on the occupation decisions of recent graduates.

From a policy perspective perhaps the most important question is not how the probability of remaining in teaching changes as the wage rises, but how many extra graduates in total would be in teaching if the wage increase was adopted. Unfortunately, this is very difficult to answer, given that we have only modeled the teaching decisions of a small number of all the past graduates who could potentially still become teachers, and that we have not modeled wastage of teachers over their career life cycle, but merely the teacher/non-teacher decision at given points in time. All we can approximately calculate is, if relative wages for teachers are $10 \%$ higher, how many more teachers there will be in, for example 1996, amongst those who graduated in 1990. We do this by simply applying the probabilities of individuals teaching to the known number of graduates in each of the years. Thus, for example, if relative teacher wages were 10\% higher, an additional 11,360 1990 graduates would be teaching in 1996, as revealed in the final row of Table 2. This might give us some idea of how the current cohort of graduates would react if relative wages were to rise now, although even this prediction must be treated with caution, based as it on the behaviour of a cohort who graduated over ten years ago. How older cohorts of graduates, who have already chosen alternative careers, 
would react to an increase in wages now is impossible to predict based on the above analysis, although we can assume that the increased numbers choosing to switch into teaching would be smaller than the increased supply of new graduates from the current cohort into teaching, since inertia effects reduce the likelihood of career switches amongst those already in work. The results suggest that the effect of a pay rise now will be increasingly smaller, the older the cohort of graduates that we consider. Overall, however, it is not possible, based on the above analysis, to give a precise answer to the question of by how much would teachers' pay have to rise to generate the 34,000 extra teachers that would eliminate the excess demand for teachers.

\section{Conclusion}

There currently exists a large excess demand for teachers in the UK, of approximately 34,000 individuals. Given the limited control that the Government has over the demand for teachers, controlled mostly as it is by the number of pupils, the best hope for narrowing this gap between demand and supply is to increase supply. Yet the results show that, with the exception of the recession years of the early 1980s, each cohort in our study has been successively less likely to choose teaching than the cohort before, holding other things constant. The Government clearly needs to turn around this trend away from teaching. The simplest way to do this, if funds allow, would be to relax expenditure limits, and pay higher wages to teachers, since the results show that the supply of teachers is highly responsive to the relative wages paid to them. The results suggest that, had teachers' relative pay been $10 \%$ higher in the 1990s, then over 11,000 more graduates of 1990 would have been teachers in 1996. What we cannot tell from our analysis, however, is the impact of a pay rise now on the current graduate cohort, as well as the effect on earlier graduates who have chosen alternative careers, or indeed on the quit behaviour of those who chose to be teachers. As a minimum, our results do suggest that the extent to which a pay rise for teachers will solve the problems of shortage will depend on the state of the labour market at the time. More specifically, if relative teacher earnings are low (as in 1986) or teachers have experienced several successive years of decline (as in 1996) then the potential for shifting a shortage by raising teacher pay is greatly increased. 
The other key results from this study relate to possible supply deficits in particular subjects and geographical areas. The results reveal that graduates in engineering, sciences and social sciences are particularly unlikely to choose teaching as a career. Even if earnings were the same, the alternative professional occupations available for such graduates are likely to tempt them away from teaching, if working conditions in teaching are not well regarded. The fact that wages will probably be higher in these alternative professions simply acts to reinforce this trend. The trend manifests itself in the well-publicised lack of maths and science teachers. Similarly, graduates in London are also less likely than those in other regions to be teachers, again presumably because of the large number of alternative professions open to them in the nation's capital. The theoretical model above described how it could be possible to equate demand and supply of teachers in each of the different subjects or regions, if the Government is willing to pay different wages to different teachers, and can persuade the teaching unions to accept such a system. Again, however the empirical results above cannot predict exactly what the wage differences between subjects would have to be to eliminate specific shortages, since our analysis dealt with aggregates, rather than specific sub-groups, due to small sample sizes in the various data cells that define these groups.

The UK Government has actually recently implemented pay rises to teachers, but made them conditional on performance $^{10}$. After approximately seven years of service, teachers can apply to 'cross the threshold', success at which leads to an immediate $£ 2000$ pay rise and access to a higher pay scale. Presumably this approach, rather than a general pay rise, was adopted in order to achieve the twin aims of increasing the quantity and quality of teachers. The results above showed that quality should also be a consideration, given that graduates with the highest level degrees are less likely to choose to teach. What the results cannot predict, however, is the success of the Government's Performance Related Pay scheme, since no such scheme was present during the years of our study. Thus, although the supply of teachers is highly responsive to the relative wage rate, it remains to be seen whether a higher wage for teachers that is tied to performance has a similar effect in increasing supply.

${ }^{10}$ Although note that it is expected that the majority of teachers will receive the higher payments. 


\section{References}

Ballou, D. and Podgursky (1995) 'Recruiting smarter teachers,' Journal of Human Resources, 30, 326-338.

Brewer, D.J. (1996) 'Career paths and quit decisions: evidence from teaching,' Journal of Labor Economics, 14, 313-339.

Chevalier, A. and Walker, I. (2001) 'Further results on the returns to education in the UK,' in Harmon, C.,Walker, I. and Westergard-Nielsen, N. (Eds) Education and Earnings in Europe: A Cross Country Analysis of Returns to Education, Edward-Elgar

Chevalier, A., Dolton, P. and McIntosh, S. (2001) 'The Job Satisfaction of UK Teachers,' mimeo.

Dolton, P. (1990) 'The economics of UK teacher supply: the graduate's decision,' Economic Journal, 100, conference papers, 91-104.

Dolton, P. and Mavromaras (1994) 'Intergenerational occupational choice comparisons: the case of teachers in the UK,' Economic Journal, 104, 841-863.

Dolton, P. and van der Klaauw, W. (1995a) 'Leaving teaching in the UK: a duration analysis,' Economic Journal, 105, 431-444.

Dolton, P. and van der Klaauw, W. (1995b) 'Teaching salaries and teacher retention,' in Baumol, W. and Becker, W. (eds) Assessing Educational Practices: The Contribution of Economics, Cambridge MA, MIT Press.

Dolton, P. and van der Klaauw, W. (1999) 'The turnover of teachers: a competing risks explanation,' Review of Economics and Statistics, 81, 543-552.

Flyer, F. and Rosen, S. (1997) 'The new economics of teachers and education,' Journal of Labor Economics, 15, S104-S139.

Hanushek, E.A., Kain, J.F. and Rivkin, S.G. (1999) 'Do higher salaries buy better teachers?' National Bureau of Economic Research, Working paper 7082.

Manski, C.F. (1987) 'Academic ability, earnings, and the decision to become a teacher: evidence from the National Longitudinal Study of the High School Class of 1972,' in Wise, D. (ed) Public Sector Payrolls, Chicago IL, University of Chicago Press.

Mont, D. and Rees, D.I. (1996) 'The influence of classroom characteristics on high school teacher turnover,' Economic Inquiry, 34, 152-167.

Murnane, R.J. and Olsen, R.J. (1989) 'The effects of salaries and opportunity costs on duration in teaching: evidence from Michigan,' Review of Economics and Statistics, 71, 347352. 
Murnane, R.J. and Olsen, R.J. (1990) 'The effects of salaries and opportunity costs on length of stay in teaching: evidence from North Carolina,' Journal of Human Resources, 25, 106124.

Rees, D.I. (1991) 'Grievance procedure strength and teacher quits,' Industrial and Labor Relations Review, 45, 31-43.

Rosenbaum, P. and Rubin, D. (1983) 'The central role of the propensity score in observational studies for causal effects', Biometrika, 70, 1, 41-55.

Stinebrickner, T.R. (1998) 'An empirical investigation of teacher attrition,' Economics of Education Review, 17, 127-136.

Stinebrickner, T.R. (2001) 'A dynamic model of teacher labor supply,' Journal of Labor Economics, 19, 196-230.

Theobald, N.D (1990) 'An examination of the influence of personal, professional, and school district characteristics on public school teacher retention,' Economics of Education Review, 9, 241-250.

Theobald, N.D. and Gritz, R.M. (1996) 'The effects of school district spending priorities on the exit paths of beginning teachers leaving the district,' Economics of Education Review, 15, $11-22$.

Zabalza, A., Turnbull, P. and Williams, G. (1979) The Economics of Teacher Supply, Cambridge, Cambridge University Press. 


\section{Appendix A}

\section{The Excess Demand for Teachers}

In the text, it was claimed that there is currently, in the year 2000, an excess demand for 34,000 teachers. This figure, and similar figures for earlier years as depicted in Figure A1 below, were calculated according to DfES released figures. The demand for teachers is determined by the number of pupils, and the Government's published desired pupil teacher ratio. For example, in 2000, there were 4,278,123 primary school children (full-time equivalents. The Government desired that there would be 21.2 primary school children for every primary school teacher, implying that 210,798 primary school teachers are demanded. In actual fact, there were 183,762 primary school teachers in 2000 , implying an excess demand for primary school teachers of 18,036. A similar analysis for secondary school teachers reveals that there was an excess demand of 15,952 teachers, giving the overall excess demand figure of approximately 34,000, as quoted above. Figure 1 reveals the situation for all years since 1946. The graph shows that there has been an excess demand for teachers almost continuously throughout this period. This has principally been for secondary school teachers, although the difference in the excess demand for primary and secondary school teachers disappeared towards the end of the 1990s.

Figure A1 Excess Demand for Teachers

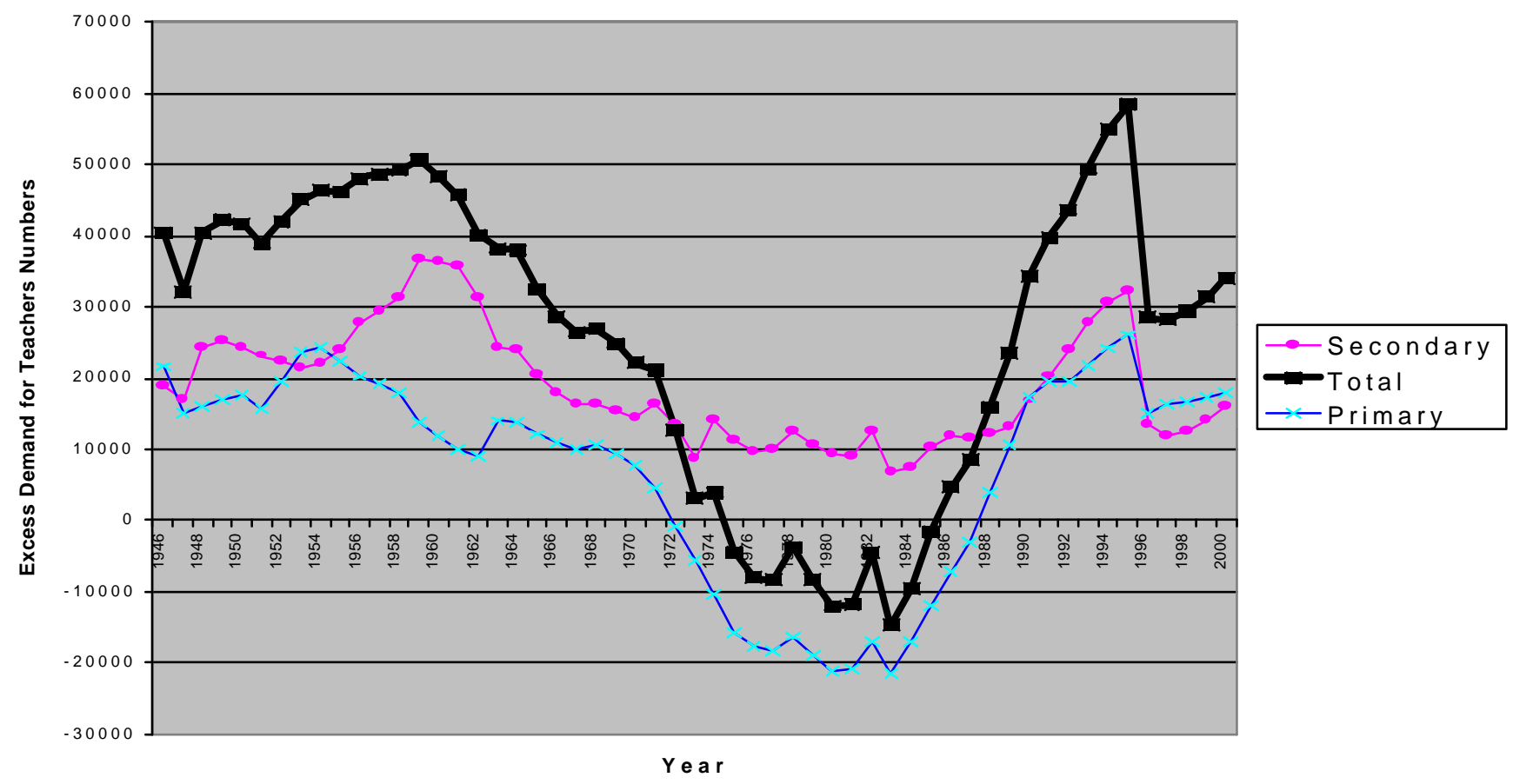


Figure A2 - The Labour Market for Teachers

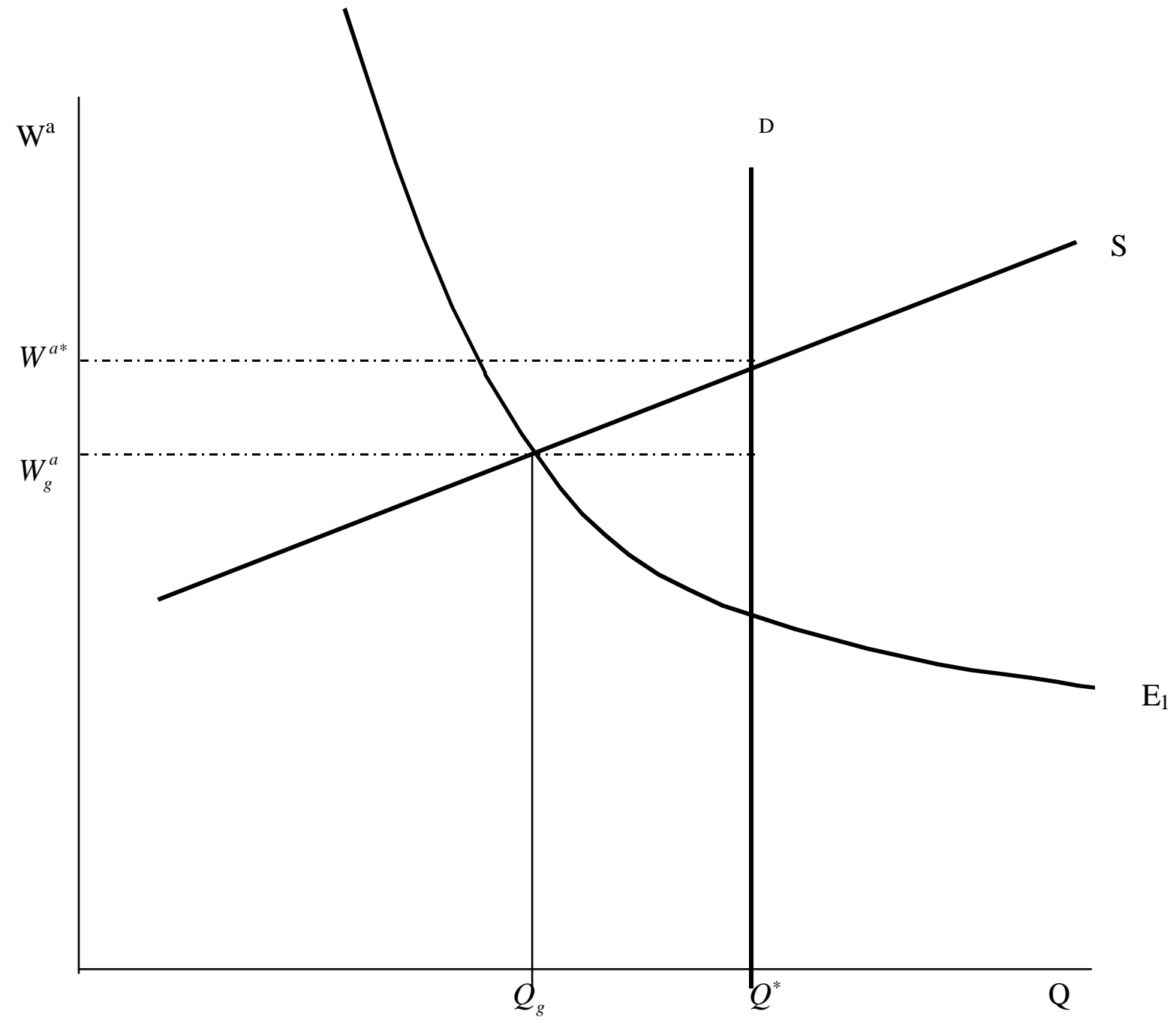


Table A1 : Summary Statistics

\begin{tabular}{|c|c|c|c|c|c|}
\hline & 1960 & 1970 & 1980 & 1985 & 1990 \\
\hline \multirow{2}{*}{ Ln current wage } & 8.235 & 8.253 & 8.094 & 8.526 & 8.256 \\
\hline & $(0.516)$ & $(0.394)$ & $(0.408)$ & $(0.523)$ & $(0.407)$ \\
\hline Teacher & 0.279 & 0.153 & 0.139 & 0.112 & 0.138 \\
\hline Male & 0.700 & 0.809 & 0.634 & 0.592 & 0.502 \\
\hline First and $2 / 1$ degree class & 0.284 & 0.309 & 0.358 & 0.399 & 0.476 \\
\hline \multirow{2}{*}{ Alevel score } & 9.635 & 8.287 & 7.718 & 9.113 & 7.412 \\
\hline & (2.919) & (4.164) & $(4.088)$ & $(4.337)$ & $(4.497)$ \\
\hline Alevel score missing & 0.014 & 0.094 & 0.071 & 0.093 & 0.148 \\
\hline Professional qualification & 0.136 & 0.195 & 0.221 & 0.299 & 0.220 \\
\hline Phd & 0.096 & 0.073 & 0.053 & 0.019 & 0.008 \\
\hline Msc & 0.049 & 0.065 & 0.068 & 0.131 & 0.098 \\
\hline Mature student & 0.071 & 0.055 & 0.070 & 0.100 & 0.161 \\
\hline London and South-East & 0.130 & 0.241 & 0.260 & 0.220 & 0.214 \\
\hline Attended a university & 1.000 & 0.704 & 0.668 & 0.828 & 0.454 \\
\hline Science & 0.132 & 0.229 & 0.148 & 0.166 & 0.162 \\
\hline Social science & 0.291 & 0.347 & 0.269 & 0.310 & 0.249 \\
\hline Language & 0.172 & 0.252 & 0.269 & 0.263 & 0.304 \\
\hline Arts & 0.112 & 0.098 & 0.081 & 0.105 & 0.074 \\
\hline Others & 0.163 & 0.050 & 0.105 & 0.080 & 0.092 \\
\hline Married & 0.681 & 0.695 & 0.547 & 0.628 & 0.377 \\
\hline Private school & 0.211 & 0.273 & 0.113 & 0.206 & 0.153 \\
\hline Dad: Semi skilled & 0.087 & 0.045 & 0.033 & 0.050 & 0.043 \\
\hline Dad: Skilled manual & 0.187 & 0.228 & 0.091 & 0.136 & 0.157 \\
\hline Dad: Skilled non-manual & 0.265 & 0.142 & 0.267 & 0.079 & 0.084 \\
\hline Dad: Interim occupation & 0.216 & 0.397 & 0.422 & 0.301 & 0.293 \\
\hline Dad: Professional & 0.192 & 0.178 & 0.181 & 0.351 & 0.328 \\
\hline Observations & 4877 & 4492 & 4782 & 1529 & 2312 \\
\hline
\end{tabular}

Note: standard deviations in parentheses for the continuous variables. 
Table A2: First job teaching status

\begin{tabular}{|c|c|c|}
\hline & Coef & Marginal effects \\
\hline Male & $\begin{array}{l}-0.498 \\
(17.75)^{* *}\end{array}$ & $\begin{array}{l}-0.093 \\
(17.75)^{* *}\end{array}$ \\
\hline First and $2 / 1$ class degree & $\begin{array}{l}-0.092 \\
(3.08) * *\end{array}$ & $\begin{array}{l}-0.015 \\
(3.08)^{* *}\end{array}$ \\
\hline A-level score & $\begin{array}{l}-0.004 \\
(0.85)\end{array}$ & $\begin{array}{l}-0.001 \\
(0.85)\end{array}$ \\
\hline A-level score missing & $\begin{array}{l}0.010 \\
(0.15)\end{array}$ & $\begin{array}{l}0.002 \\
(0.15)\end{array}$ \\
\hline Professsional qualification & $\begin{array}{l}-1.029 \\
(20.38)^{* *}\end{array}$ & $\begin{array}{l}-0.116 \\
(20.38)^{* *}\end{array}$ \\
\hline Phd & $\begin{array}{l}-0.867 \\
(10.95)^{* *}\end{array}$ & $\begin{array}{l}-0.086 \\
(10.95)^{* *}\end{array}$ \\
\hline $\mathrm{Msc}$ & $\begin{array}{l}-0.217 \\
(3.73)^{* *}\end{array}$ & $\begin{array}{l}-0.032 \\
(3.73)^{* *}\end{array}$ \\
\hline Mature student & $\begin{array}{l}0.322 \\
(6.88)^{* * *}\end{array}$ & $\begin{array}{l}0.064 \\
(6.88)^{* *}\end{array}$ \\
\hline London and South-East & $\begin{array}{l}-0.499 \\
(11.64)^{* *}\end{array}$ & $\begin{array}{l}-0.068 \\
(11.64)^{* *}\end{array}$ \\
\hline Attended a university & $\begin{array}{l}-0.032 \\
(0.84)\end{array}$ & $\begin{array}{l}-0.005 \\
(0.84)\end{array}$ \\
\hline Cohort70 & $\begin{array}{l}-0.038 \\
(1.00)\end{array}$ & $\begin{array}{l}-0.006 \\
(1.00)\end{array}$ \\
\hline Cohort 80 & $\begin{array}{l}-0.625 \\
(15.56)^{* *}\end{array}$ & $\begin{array}{l}-0.086 \\
(15.56)^{* *}\end{array}$ \\
\hline Cohort 85 & $\begin{array}{l}-0.790 \\
(13.41) * *\end{array}$ & $\begin{array}{l}-0.084 \\
(13.41)^{* *}\end{array}$ \\
\hline Cohort 90 & $\begin{array}{l}-0.890 \\
(17.47)^{* *}\end{array}$ & $\begin{array}{l}-0.096 \\
(17.47)^{* *}\end{array}$ \\
\hline Engineer & $\begin{array}{l}-2.176 \\
(26.84) * *\end{array}$ & $\begin{array}{l}-0.168 \\
(26.84) * *\end{array}$ \\
\hline Science & $\begin{array}{l}-0.974 \\
(23.04) * *\end{array}$ & $\begin{array}{l}-0.128 \\
(23.04) * *\end{array}$ \\
\hline Social science & $\begin{array}{l}-1.077 \\
(24.19) * *\end{array}$ & $\begin{array}{l}-0.128 \\
(24.19) * *\end{array}$ \\
\hline Language & $\begin{array}{l}-0.540 \\
(11.08)^{* *}\end{array}$ & $\begin{array}{l}-0.067 \\
(11.08)^{* *}\end{array}$ \\
\hline Arts & $\begin{array}{l}-0.447 \\
(9.47)^{* *}\end{array}$ & $\begin{array}{l}-0.059 \\
(9.47)^{* *}\end{array}$ \\
\hline Private school & $\begin{array}{l}-0.317 \\
(8.32)^{* *}\end{array}$ & $\begin{array}{l}-0.046 \\
(8.32)^{* *}\end{array}$ \\
\hline Dad: Semi-skilled & $\begin{array}{l}0.123 \\
(1.53)\end{array}$ & $\begin{array}{l}0.022 \\
(1.53)\end{array}$ \\
\hline Dad: Skilled manual & $\begin{array}{l}0.025 \\
(0.35)\end{array}$ & $\begin{array}{l}0.004 \\
(0.35)\end{array}$ \\
\hline Dad: Skilled non manual & $\begin{array}{l}-0.048 \\
(0.68)\end{array}$ & $\begin{array}{l}-0.008 \\
(0.68)\end{array}$ \\
\hline Dad: Interim occupation & $\begin{array}{l}-0.152 \\
(2.24)^{*}\end{array}$ & $\begin{array}{l}-0.025 \\
(2.24)^{*}\end{array}$ \\
\hline Dad: Professional & $\begin{array}{l}-0.196 \\
(2.78)^{* *}\end{array}$ & $\begin{array}{l}-0.030 \\
(2.78)^{* *}\end{array}$ \\
\hline Constant & $\begin{array}{l}0.963 \\
(11.13)^{* *}\end{array}$ & \\
\hline Observations & 17992 & 17992 \\
\hline
\end{tabular}

All standard error are corrected for heteroskedasticity.

$*, * *$ indicate significance at the $10 \%$ and $5 \%$ level respectively 
Table A3 : The Determinants of Current wages

\begin{tabular}{|c|c|c|c|}
\hline & Selection & Teachers & Non-teacher \\
\hline \multirow[t]{2}{*}{ Male } & -0.511 & 0.107 & 0.162 \\
\hline & $(18.39)^{* *}$ & $(6.63)^{* *}$ & $(17.44)^{* *}$ \\
\hline \multirow[t]{2}{*}{ First and 2/1 class degree } & -0.105 & 0.053 & 0.055 \\
\hline & $(3.55)^{* *}$ & $(4.99)^{* *}$ & $(7.65)^{* *}$ \\
\hline \multirow[t]{2}{*}{ A-level score } & -0.009 & 0.002 & 0.007 \\
\hline & $(1.94)^{*}$ & $(1.05)$ & $(5.87)^{* *}$ \\
\hline \multirow[t]{2}{*}{ A-level score missing } & -0.117 & 0.037 & 0.058 \\
\hline & $(1.74)^{*}$ & $(1.56)$ & $(3.66)^{* *}$ \\
\hline \multirow[t]{2}{*}{ Professional qualification } & -1.132 & 0.037 & 0.055 \\
\hline & $(22.51)^{* *}$ & $(0.91)$ & $(5.12)^{* *}$ \\
\hline \multirow[t]{2}{*}{ Phd } & -0.891 & 0.174 & 0.172 \\
\hline & $(11.60) * *$ & $(3.67)^{* *}$ & $(10.20)^{* *}$ \\
\hline \multirow[t]{2}{*}{ Msc } & -0.317 & 0.063 & 0.077 \\
\hline & $(5.41)^{* *}$ & $(2.50)^{* *}$ & $(6.12)^{* *}$ \\
\hline \multirow[t]{2}{*}{ Mature student } & 0.176 & 0.064 & 0.006 \\
\hline & $(3.63)^{* *}$ & $(3.71)^{* *}$ & $(0.46)$ \\
\hline \multirow[t]{2}{*}{ London and South-East } & -0.524 & 0.114 & 0.133 \\
\hline & $(14.52)^{* *}$ & $(5.47)^{* *}$ & $(15.17)^{* *}$ \\
\hline \multirow[t]{2}{*}{ Attended a university } & 0.000 & 0.021 & 0.027 \\
\hline & $(0.01)$ & (1.49) & $(3.03)^{* *}$ \\
\hline \multirow[t]{2}{*}{ Experience } & & 0.005 & 0.001 \\
\hline & & $(3.49)^{* *}$ & $(1.70)^{*}$ \\
\hline \multirow[t]{2}{*}{ Experience2 } & & 0.000 & 0.000 \\
\hline & & $(0.38)$ & $(6.62)^{* *}$ \\
\hline \multirow[t]{2}{*}{ Part-time } & & -0.847 & -0.977 \\
\hline & & $(47.18)^{* *}$ & $(49.97)^{* *}$ \\
\hline \multirow[t]{2}{*}{ Cohort70 } & -0.034 & 0.001 & -0.141 \\
\hline & $(0.94)$ & $(0.07)$ & $(14.45)^{* *}$ \\
\hline \multirow[t]{2}{*}{ Cohort 80} & -0.488 & -0.170 & -0.241 \\
\hline & $(12.78)^{* *}$ & $(8.87)^{* *}$ & $(23.03)^{* *}$ \\
\hline Cohort 85 & -0.509 & $-0 . .070$ & -0.383 \\
\hline & $(9.02)^{* *}$ & $(1.40)$ & $(10.19)^{* *}$ \\
\hline Cohort 90 & -0.538 & 0.126 & -0.060 \\
\hline & $(10.44)^{* *}$ & $(5.16)^{* *}$ & $(4.44)^{* *}$ \\
\hline Engineer & -1.810 & 0.114 & 0.018 \\
\hline & $(27.84)^{* *}$ & $(1.84)^{*}$ & $(0.82)$ \\
\hline Science & -0.851 & 0.077 & 0.002 \\
\hline & $(20.57)^{* *}$ & $(3.00)^{* *}$ & $(0.11)$ \\
\hline Social science & -0.967 & 0.087 & 0.015 \\
\hline & $(21.85)^{* *}$ & $(2.86)^{* *}$ & $(0.82)$ \\
\hline Language & -0.393 & 0.048 & -0.066 \\
\hline & $(8.18)^{* *}$ & $(2.71)^{* *}$ & $(3.65)^{* *}$ \\
\hline Arts & -0.331 & 0.037 & -0.089 \\
\hline & $(7.06)^{* *}$ & $(2.20)^{* *}$ & $(5.03)^{* *}$ \\
\hline Married & 0.074 & & \\
\hline & $(2.73)^{* *}$ & & \\
\hline Private school & -0.239 & & \\
\hline & $(6.58)^{* *}$ & & \\
\hline Dad: Semi-skilled & 0.172 & & \\
\hline & $(2.13)^{* *}$ & & \\
\hline Dad: Skilled manual & 0.052 & & \\
\hline & $(0.74)$ & & \\
\hline Dad: Skilled non manual & 0.001 & & \\
\hline & $(0.01)$ & & \\
\hline Dad: Interim occupation & -0.133 & & \\
\hline & $(1.95)^{*}$ & & \\
\hline Dad: Professional & -0.205 & & \\
\hline & $(2.91)^{* *}$ & & \\
\hline Lambda & & -0.104 & -0.164 \\
\hline & & $(2.75)^{* *}$ & $(-5.32)^{* *}$ \\
\hline Constant & 0.771 & 7.747 & 7.855 \\
\hline & $(8.84)^{* *}$ & $(157.38)^{* *}$ & $(185.30)^{* *}$ \\
\hline Observations & 17992 & $3201 / 17992$ & $14791 / 17992$ \\
\hline
\end{tabular}

All standard error are corrected for heteroskedasticity. * ** significance at the $10 \%$ and $5 \%$ level respectively 
Table A4: The Determinants of Current Teaching Status:

\begin{tabular}{|c|c|c|}
\hline & Coefficient & Marginal effect \\
\hline Male & $\begin{array}{l}-0.215 \\
(4.54)^{* *}\end{array}$ & $\begin{array}{l}-0.040 \\
(4.54)^{* *}\end{array}$ \\
\hline First and $2 / 1$ class degree & $\begin{array}{l}-0.089 \\
(2.98)^{* * *}\end{array}$ & $\begin{array}{l}-0.016 \\
(2.98)^{* *}\end{array}$ \\
\hline A-level score & $\begin{array}{l}0.006 \\
(1.20)\end{array}$ & $\begin{array}{l}0.001 \\
(1.20)\end{array}$ \\
\hline A-level score missing & $\begin{array}{l}-0.049 \\
(0.73)\end{array}$ & $\begin{array}{l}-0.009 \\
(0.73)\end{array}$ \\
\hline Professional qualification & $\begin{array}{l}-0.973 \\
(14.00)^{* *}\end{array}$ & $\begin{array}{l}-0.121 \\
(14.00)^{* *}\end{array}$ \\
\hline Phd & $\begin{array}{l}-0.895 \\
(9.53)^{* *}\end{array}$ & $\begin{array}{l}-0.095 \\
(9.53)^{* *}\end{array}$ \\
\hline Msc & $\begin{array}{l}-0.291 \\
(4.82)^{* *}\end{array}$ & $\begin{array}{l}-0.044 \\
(4.82)^{* *}\end{array}$ \\
\hline Mature student & $\begin{array}{l}-0.028 \\
(0.51)\end{array}$ & $\begin{array}{l}-0.005 \\
(0.51)\end{array}$ \\
\hline London and South-East & $\begin{array}{l}-0.431 \\
(10.77)^{* *}\end{array}$ & $\begin{array}{l}-0.066 \\
(10.77)^{* *}\end{array}$ \\
\hline Attended a university & $\begin{array}{l}0.015 \\
(0.41)\end{array}$ & $\begin{array}{l}0.003 \\
(0.41)\end{array}$ \\
\hline Cohort70 & $\begin{array}{l}-0.390 \\
(6.97)^{* *}\end{array}$ & $\begin{array}{l}-0.062 \\
(6.97)^{* * *}\end{array}$ \\
\hline Cohort 80 & $\begin{array}{l}-0.580 \\
(9.64)^{* *}\end{array}$ & $\begin{array}{l}-0.088 \\
(9.64)^{* *}\end{array}$ \\
\hline Cohort 85 & $\begin{array}{l}-0.511 \\
(6.73)^{* *}\end{array}$ & $\begin{array}{l}-0.069 \\
(6.73)^{* *}\end{array}$ \\
\hline Cohort 90 & $\begin{array}{l}-0.953 \\
(10.43)^{* *}\end{array}$ & $\begin{array}{l}-0.109 \\
(10.43)^{* *}\end{array}$ \\
\hline Engineer & $\begin{array}{l}-1.840 \\
(14.05)^{* *}\end{array}$ & $\begin{array}{l}-0.167 \\
(14.05)^{* *}\end{array}$ \\
\hline Science & $\begin{array}{l}-0.926 \\
(11.43)^{* *}\end{array}$ & $\begin{array}{l}-0.133 \\
(11.43)^{* *}\end{array}$ \\
\hline Social science & $\begin{array}{l}-1.034 \\
(12.07)^{* *}\end{array}$ & $\begin{array}{l}-0.135 \\
(12.07)^{* *}\end{array}$ \\
\hline Language & $\begin{array}{l}-0.675 \\
(9.12)^{* *}\end{array}$ & $\begin{array}{l}-0.085 \\
(9.12)^{* *}\end{array}$ \\
\hline Arts & $\begin{array}{l}-0.664 \\
(9.20)^{* *}\end{array}$ & $\begin{array}{l}-0.084 \\
(9.20)^{* *}\end{array}$ \\
\hline Married & $\begin{array}{l}0.059 \\
(2.16)^{*}\end{array}$ & $\begin{array}{l}0.010 \\
(2.16)^{*}\end{array}$ \\
\hline Private school & $\begin{array}{l}-0.203 \\
(4.93)^{* *}\end{array}$ & $\begin{array}{l}-0.034 \\
(4.93)^{* *}\end{array}$ \\
\hline Dad: Semi-skilled & $\begin{array}{l}0.145 \\
(1.81)^{*}\end{array}$ & $\begin{array}{l}0.028 \\
(1.81)^{*}\end{array}$ \\
\hline Dad: Skilled manual & $\begin{array}{l}0.054 \\
(0.78)\end{array}$ & $\begin{array}{l}0.010 \\
(0.78)\end{array}$ \\
\hline Dad: Skilled non manual & $\begin{array}{l}0.004 \\
(0.05)\end{array}$ & $\begin{array}{l}0.001 \\
(0.05)\end{array}$ \\
\hline Dad: Interim occupation & $\begin{array}{l}-0.116 \\
(1.70)^{*}\end{array}$ & $\begin{array}{l}-0.020 \\
(1.70)^{*}\end{array}$ \\
\hline Dad: Professional & $\begin{array}{l}-0.188 \\
(2.64)^{* *}\end{array}$ & $\begin{array}{l}-0.031 \\
(2.64)^{* *}\end{array}$ \\
\hline Prob. Teacher in first job & $\begin{array}{l}0.509 \\
(2.37)^{* * *}\end{array}$ & $\begin{array}{l}0.091 \\
(2.37)^{* *}\end{array}$ \\
\hline $\operatorname{Exp}(\mathrm{W}(\mathrm{T}=1)-\mathrm{W}(\mathrm{T}=0))$ & $\begin{array}{l}3.006 \\
(9.53)^{* *}\end{array}$ & $\begin{array}{l}0.539 \\
(9.53)^{* *}\end{array}$ \\
\hline Constant & $\begin{array}{l}0.597 \\
(3.20)^{* *}\end{array}$ & \\
\hline Observations & 17992 & 17992 \\
\hline
\end{tabular}


Table A5: The Determinant of Current Teaching Status, By Cohort (Marginal effects)

\begin{tabular}{|c|c|c|c|c|c|}
\hline & Cohort 60 & Cohort 70 & Cohort 80 & Cohort 85 & Cohort 90 \\
\hline Male & $\begin{array}{l}-0.011 \\
(0.33)\end{array}$ & $\begin{array}{l}0.006 \\
(0.32)\end{array}$ & $\begin{array}{l}0.024 \\
(2.25)^{* *}\end{array}$ & $\begin{array}{l}-0.045 \\
(2.88)^{* *}\end{array}$ & $\begin{array}{l}0.007 \\
(0.50)\end{array}$ \\
\hline First or $2 / 1$ & $\begin{array}{l}-0.042 \\
(2.50)^{* *}\end{array}$ & $\begin{array}{l}-0.011 \\
(0.93)\end{array}$ & $\begin{array}{l}-0.002 \\
(0.32)\end{array}$ & $\begin{array}{l}-0.003 \\
(0.18)\end{array}$ & $\begin{array}{l}0.061 \\
(4.45)^{* *}\end{array}$ \\
\hline A-levels score & $\begin{array}{l}-0.001 \\
(0.44)\end{array}$ & $\begin{array}{l}0.002 \\
(1.04)\end{array}$ & $\begin{array}{l}-0.000 \\
(0.19)\end{array}$ & $\begin{array}{l}0.003 \\
(1.09)\end{array}$ & $\begin{array}{l}0.010 \\
(3.59)^{* * *}\end{array}$ \\
\hline A-level missing & $\begin{array}{l}-0.127 \\
(2.48)^{* *}\end{array}$ & $\begin{array}{l}-0.003 \\
(0.12)\end{array}$ & $\begin{array}{l}-0.033 \\
(2.77)^{* *}\end{array}$ & $\begin{array}{l}0.049 \\
(1.18)\end{array}$ & $\begin{array}{l}0.104 \\
(3.05)^{* * *}\end{array}$ \\
\hline Professional qual. & $\begin{array}{l}-0.194 \\
(4.21)^{* *}\end{array}$ & $\begin{array}{l}-0.069 \\
(2.63) * *\end{array}$ & $\begin{array}{l}-0.052 \\
(4.27) * *\end{array}$ & $\begin{array}{l}-0.015 \\
(0.89)\end{array}$ & $\begin{array}{l}-0.052 \\
(4.04)^{* *}\end{array}$ \\
\hline Ph.D. & $\begin{array}{l}-0.163 \\
(3.61)^{* *}\end{array}$ & $\begin{array}{l}-0.049 \\
(2.74)^{* *}\end{array}$ & $\begin{array}{l}-0.066 \\
(5.11)^{* *}\end{array}$ & & \\
\hline Master & $\begin{array}{l}-0.115 \\
(3.95)^{* *}\end{array}$ & $\begin{array}{l}-0.017 \\
(0.85)\end{array}$ & $\begin{array}{l}-0.034 \\
(2.63)^{* *}\end{array}$ & $\begin{array}{l}-0.005 \\
(0.31)\end{array}$ & $\begin{array}{l}0.185 \\
(4.96)^{* *}\end{array}$ \\
\hline Mature student & $\begin{array}{l}-0.031 \\
(1.27)\end{array}$ & $\begin{array}{l}-0.029 \\
(1.45)\end{array}$ & $\begin{array}{l}-0.050 \\
(5.72)^{* *}\end{array}$ & $\begin{array}{l}-0.015 \\
(0.68)\end{array}$ & $\begin{array}{l}-0.014 \\
(0.68)\end{array}$ \\
\hline London & $\begin{array}{l}-0.162 \\
(9.63)^{* *}\end{array}$ & $\begin{array}{l}-0.035 \\
(3.00)^{* *}\end{array}$ & $\begin{array}{l}0.013 \\
(1.12)\end{array}$ & $\begin{array}{l}-0.058 \\
(4.20)^{* *}\end{array}$ & $\begin{array}{l}0.081 \\
(3.56) * *\end{array}$ \\
\hline University & & $\begin{array}{l}0.019 \\
(1.50)\end{array}$ & $\begin{array}{l}0.004 \\
(0.42)\end{array}$ & $\begin{array}{l}-0.000 \\
(0.03)\end{array}$ & $\begin{array}{l}-0.005 \\
(0.42)\end{array}$ \\
\hline Engineering & $\begin{array}{l}-0.180 \\
(3.30)^{* *}\end{array}$ & $\begin{array}{l}-0.082 \\
(2.84) * *\end{array}$ & $\begin{array}{l}-0.077 \\
(5.18)^{* *}\end{array}$ & $\begin{array}{l}-0.071 \\
(2.22)^{* *}\end{array}$ & $\begin{array}{l}-0.095 \\
(2.81)^{* *}\end{array}$ \\
\hline Science & $\begin{array}{l}-0.055 \\
(1.92)^{*}\end{array}$ & $\begin{array}{l}0.008 \\
(0.30)\end{array}$ & $\begin{array}{l}-0.061 \\
(4.47)^{* *}\end{array}$ & $\begin{array}{l}-0.086 \\
(1.85)^{*}\end{array}$ & $\begin{array}{l}-0.103 \\
(2.49)^{* *}\end{array}$ \\
\hline Social science & $\begin{array}{l}-0.040 \\
(1.26)\end{array}$ & $\begin{array}{l}-0.011 \\
(0.39)\end{array}$ & $\begin{array}{l}-0.069 \\
(4.65)^{* *}\end{array}$ & $\begin{array}{l}-0.089 \\
(2.08)^{* *}\end{array}$ & $\begin{array}{l}-0.132 \\
(2.80)^{* *}\end{array}$ \\
\hline Language & $\begin{array}{l}0.033 \\
(1.35)\end{array}$ & $\begin{array}{l}-0.018 \\
(0.62)\end{array}$ & $\begin{array}{l}-0.068 \\
(7.67)^{* *}\end{array}$ & $\begin{array}{l}-0.043 \\
(1.25)\end{array}$ & $\begin{array}{l}-0.082 \\
(4.57)^{* *}\end{array}$ \\
\hline Arts & $\begin{array}{l}0.018 \\
(0.80)\end{array}$ & $\begin{array}{l}-0.021 \\
(0.72)\end{array}$ & $\begin{array}{l}-0.030 \\
(2.64)^{* *}\end{array}$ & $\begin{array}{l}-0.047 \\
(1.41)\end{array}$ & $\begin{array}{l}-0.087 \\
(4.37)^{* *}\end{array}$ \\
\hline Married & $\begin{array}{l}-0.037 \\
(2.66)^{* *}\end{array}$ & $\begin{array}{l}0.012 \\
(1.24)\end{array}$ & $\begin{array}{l}0.026 \\
(3.83)^{* *}\end{array}$ & $\begin{array}{l}0.024 \\
(2.08)^{* *}\end{array}$ & $\begin{array}{l}0.002 \\
(0.15)\end{array}$ \\
\hline Private school & $\begin{array}{l}-0.038 \\
(1.41)\end{array}$ & $\begin{array}{l}-0.004 \\
(0.35)\end{array}$ & $\begin{array}{l}-0.017 \\
(1.47)\end{array}$ & $\begin{array}{l}0.001 \\
(0.07)\end{array}$ & $\begin{array}{l}-0.024 \\
(1.60)\end{array}$ \\
\hline Dad: semi-skilled & $\begin{array}{l}0.120 \\
(2.99)^{* *}\end{array}$ & $\begin{array}{l}-0.026 \\
(0.67)\end{array}$ & $\begin{array}{l}0.040 \\
(0.65)\end{array}$ & $\begin{array}{l}-0.026 \\
(1.02)\end{array}$ & $\begin{array}{l}-0.007 \\
(0.26)\end{array}$ \\
\hline Dad: skilled manual & $\begin{array}{l}0.058 \\
(1.86)^{*}\end{array}$ & $\begin{array}{l}-0.016 \\
(0.42)\end{array}$ & $\begin{array}{l}0.049 \\
(0.82)\end{array}$ & $\begin{array}{l}-0.010 \\
(0.45)\end{array}$ & $\begin{array}{l}-0.028 \\
(1.83)^{*}\end{array}$ \\
\hline Dad: skilled non manual & $\begin{array}{l}0.042 \\
(1.42)\end{array}$ & $\begin{array}{l}-0.026 \\
(0.70)\end{array}$ & $\begin{array}{l}0.044 \\
(0.82)\end{array}$ & $\begin{array}{l}0.054 \\
(1.58)\end{array}$ & $\begin{array}{l}-0.041 \\
(2.48)^{* *}\end{array}$ \\
\hline Dad: Interim occupation & $\begin{array}{l}0.032 \\
(1.04)\end{array}$ & $\begin{array}{l}-0.044 \\
(1.17)\end{array}$ & $\begin{array}{l}0.016 \\
(0.32)\end{array}$ & $\begin{array}{l}0.002 \\
(0.12)\end{array}$ & $\begin{array}{l}-0.032 \\
(2.02)^{* *}\end{array}$ \\
\hline Dad: Professional & $\begin{array}{l}0.011 \\
(0.32)\end{array}$ & $\begin{array}{l}-0.052 \\
(1.50)\end{array}$ & $\begin{array}{l}0.011 \\
(0.22)\end{array}$ & $\begin{array}{l}-0.004 \\
(0.17)\end{array}$ & $\begin{array}{l}-0.032 \\
(2.04) * *\end{array}$ \\
\hline Prob. Teacher in first job & $\begin{array}{l}0.397 \\
(2.45)^{* *}\end{array}$ & $\begin{array}{l}0.334 \\
(4.46)^{* *}\end{array}$ & $\begin{array}{l}0.129 \\
(2.58)^{* *}\end{array}$ & $\begin{array}{l}0.135 \\
(1.45)\end{array}$ & $\begin{array}{l}0.119 \\
(1.12)\end{array}$ \\
\hline $\operatorname{Exp}(\mathrm{W}(\mathrm{T}=1)-\mathrm{W}(\mathrm{T}=0))$ & $\begin{array}{l}0.195 \\
(3.58)^{* *}\end{array}$ & $\begin{array}{l}0.303 \\
(4.56)^{* *}\end{array}$ & $\begin{array}{l}0.670 \\
(12.47)^{* *}\end{array}$ & $\begin{array}{l}0.141 \\
(1.75)^{*}\end{array}$ & $\begin{array}{l}0.757 \\
(6.73)^{* *}\end{array}$ \\
\hline Observations & 4877 & 4492 & 4782 & 1502 & 2296 \\
\hline
\end{tabular}

Note: $\operatorname{Exp}(\mathrm{W}(\mathrm{T}=1)-\mathrm{W}(\mathrm{T}=0))$ is the expected wage differential for the individual between teaching and nonteaching occupation.

All standard error are obtained by bootstrapping (500 replications).

$*, * *$ indicate significance at the $10 \%$ and $5 \%$ level respectively 